Revue Française de Civilisation Britannique

\title{
Neo-liberalism and Gender Inequality in the Workplace in Britain
}

Néolibéralisme et inégalités de genre dans le monde du travail britannique

Louise Dalingwater

\section{(2) OpenEdition}

\section{Journals}

Electronic version

URL: http://journals.openedition.org/rfcb/1802

DOI: $10.4000 /$ rfcb.1802

ISSN: 2429-4373

\section{Publisher}

CRECIB - Centre de recherche et d'études en civilisation britannique

Electronic reference

Louise Dalingwater, « Neo-liberalism and Gender Inequality in the Workplace in Britain », Revue Française de Civilisation Britannique [Online], XXIII-1 | 2018, Online since 20 March 2018, connection on 10 December 2020. URL : http://journals.openedition.org/rfcb/1802 ; DOI : https://doi.org/10.4000/ rfcb. 1802

This text was automatically generated on 10 December 2020 .

Revue française de civilisation britannique est mis à disposition selon les termes de la licence Creative Commons Attribution - Pas d'Utilisation Commerciale - Pas de Modification 4.0 International. 


\title{
Neo-liberalism and Gender Inequality in the Workplace in Britain
}

Néolibéralisme et inégalités de genre dans le monde du travail britannique

\author{
Louise Dalingwater
}

1 Mots clés: Le néo-libéralisme, inégalités, marché du travail britannique, ségrégation horizontale, enquête nationale

\section{Introduction}

2 There has been a significant rise in the number of women working in Britain since the 1970s. This rise is directly related to the move towards a service economy and also higher levels of education and training. In addition, a series of laws introduced since the 1970s, notably the Equal Pay Act of 1970, the Sex Discrimination Act of 1974 and the Employment Protection Act of 1982, have encouraged women to work. However, there appears to be a discrepancy between the quantity of work available for women and the quality. Quality work, as defined by the International Labour Organisation (ILO), can be described as work that provides decent pay, and offers development and progression opportunities. Many of the jobs created in the service sector, and largely occupied by women, tend to be low paid and low prospect "pink-collar" jobs, failing to meet many of the "decent work" recommendations of the ILO. ${ }^{1}$

3 Although this is true of many industrialised countries with very different labour market conditions, such as France and Germany, the pay and prospects gap for women is considerably higher in Britain. There are, of course, a number of causal effects which apply to many OECD countries. However, a body of evidence suggests that higher gender inequalities at work may be linked to neo-liberalism in Britain. To test this theory, this paper uses both empirical evidence (a two-nation survey) and a literature 
review (various reports and analysis). However, other sources also show that a diffuse gender conservatism may also explain these higher gender inequalities in Britain.

\section{How has neo-liberalism impacted on women in Britain?}

4 Neo-liberalism can be defined as an "Ideology and policy model that emphasises the value of free market competition". ${ }^{2}$ There is considerable debate on the defining features of neoliberal thought and practice. However, there does appear to be a consensus on the fact that it emphasises minimum state intervention and freedom of trade and capital. Although neo-liberalism emerged in the late 1930s during discussions held at the Walter Lipmann conference, which brought together 26 economists and liberal thinkers, it became a central part of government policy in the UK towards the late 1970s, with the decline of Keynesianism. With the arrival in power of the New Right in 1979, led by Prime Minister Margaret Thatcher, neo-liberalism was placed at the heart of economic policy in parallel with the application of neo-liberal policies in the US. This led to a whole range of organisational reforms to curb spending and reduce entitlements in order to maximise efficiency, promote competition and ensure complete responsiveness to user needs. The effects of neo-liberalism on the labour market since 1979 have been the deregulation of basic industries, the privatisation and/or contracting out of public services, a reduction in welfare programmes (lower unemployment benefits and stricter conditions to claim unemployment benefit), the marginalisation of collective bargaining, the casualisation of jobs (a decline in the number of medium to high-paying, long-term jobs and a rise in casual, low paid, less stable jobs) and unrestrained competition, putting downward pressure on wages. Neoliberalism dictates that the market situation should be taken on by the individual. He or she should enhance his or her personal capital. Dependency does not enable one to do this. In situations where market or quasi-market situations are not possible, rewards and sanctions, incentives and disincentives guide individual behaviour and choices. Even New Labour embraced the fundamental concepts of neo-liberalism. Indeed, the welfare-to-work programme introduced in 1998 was very much in line with neo-liberal rationality. In this framework, the unemployed were obliged to take responsibility for their situation and take up work. Sanctions were applied to those who did not conform to the rules of the framework.

5 Since the neo-liberal model has taken hold and become central in government policy, academics have studied the effects of neo-liberal policies on women. Some authors consider that market liberalisation may have contributed to women's empowerment. ${ }^{3}$ They argue that market liberalisation and increasing trade provides a growing number of jobs in a wide range of areas and opportunities for women to become empowered by actively contributing to the wealth and richness of the nation on the same level as men, rather than carrying out unpaid domestic chores behind closed doors. However Hawkesworth ${ }^{4}$ claims that neo-liberal policies destroy parts of the state that previously supported feminist action. For her, social mobilisation for empowerment has become fragmented and transformed into less effective individual self-improvement movements. US and British feminist writers, such as Hester Eisenstein, ${ }^{5}$ Fraser $^{6}$ and McRobbie, ${ }^{7}$ have underlined that there has been an erasure of feminist politics with the rise of neo-liberalism. Srilata Batiliwala shows how the word "empowerment" has been 
appropriated, used and abused in neo-liberal political discourse and its meaning changed. Empowerment in neo-liberal terms merely refers to exercise of individual preference or acquisition of assets. The World Bank defines empowerment as "the process of enhancing an individual's or group's capacity to make purposive choices and to transform those choices into desired actions and outcomes." ${ }^{8}$ Feminists' understanding of empowerment has a quite different meaning, that of challenging and changing norms and behaviour for female development. It is also associated with collective action.

Women are said to have been uprooted from old institutions, which focused on equal outcomes for women, and now work in a flexible economy. It can be argued that neoliberalism has changed attitudes to inequality overall. As the Gender Impact Analysis of the UK underlined, gender equality is currently a contested political priority. It would seem that tackling inequality is not a priority in government policy. Equity, fairness, eligibility, entitlement and merit have displaced inequalities as priorities of government policy. Much of the theory and analysis on the influence of neo-liberalism presented thus far would seem to suggest that neo-liberalism has an overall detrimental effect on women's advancement. The next two sections evaluate whether this is borne out in practice in the British labour market.

\section{Empirical evidence: the effects of neoliberalism on women's participation, occupation, pay and prospects}

7 Two nationwide surveys of the working population were carried out in Britain and France in 2014. Although the aim of the surveys was not only to investigate gender inequalities in the workplace but also overall wellbeing, inequalities were nevertheless a major focus of the study. Researchers Louise Dalingwater and Catherine Coron, affiliated to the CERVEPAS research centre, worked with Marketest, a leading twocountry (UK/France) statistical research company, to develop two multi-purpose questionnaires. Marketest was selected for the project because it had already collaborated with some of the leading British universities such as Cambridge University, Oxford University, LSE and Manchester University and it has a partner company in France. A panel of 1000 respondents who were in paid work in Britain and France was chosen to be representative of the working populations in terms of sex, age, region, socio-professional category and sector of activity. The surveys contained a wide range of questions relating to both objective measures of wellbeing, such as pay and prospects, but also subjective values relating to the social and physical environment of work. Within the framework of these questions, we focused on equality because substantial research has found that it can have a major impact on overall wellbeing. ${ }^{9}$

Overall, our findings showed the atypical nature of working hours in the UK. Many British people work fewer hours and some a greater number of hours than the standard 35-hour week. This can be said to be a direct result of the neo-liberal framework. As mentioned previously, deregulation has led to a more flexible labour market, which has made it easier for firms to hire and fire. In addition, companies are less burdened by fixed costs and can thus be said to be leaner and more competitive. An increasing number of workers are working on zero-hours contracts and/or very variable hours or are employed on part-time contracts. Women, in particular, tend to work part-time. ${ }^{10}$ The UK has the third highest incidence of female part-time workers in the OECD (38.7\%), which is significantly higher than that of France (22.5\%). ${ }^{11}$ Our survey found 
that the percentage was even higher if only mothers working part-time are taken into consideration. Indeed, the majority of mothers in our survey worked part-time (56\%) (see graph below).

Comparison of hours worked in Great Britain:

Parents vs. Childless workers

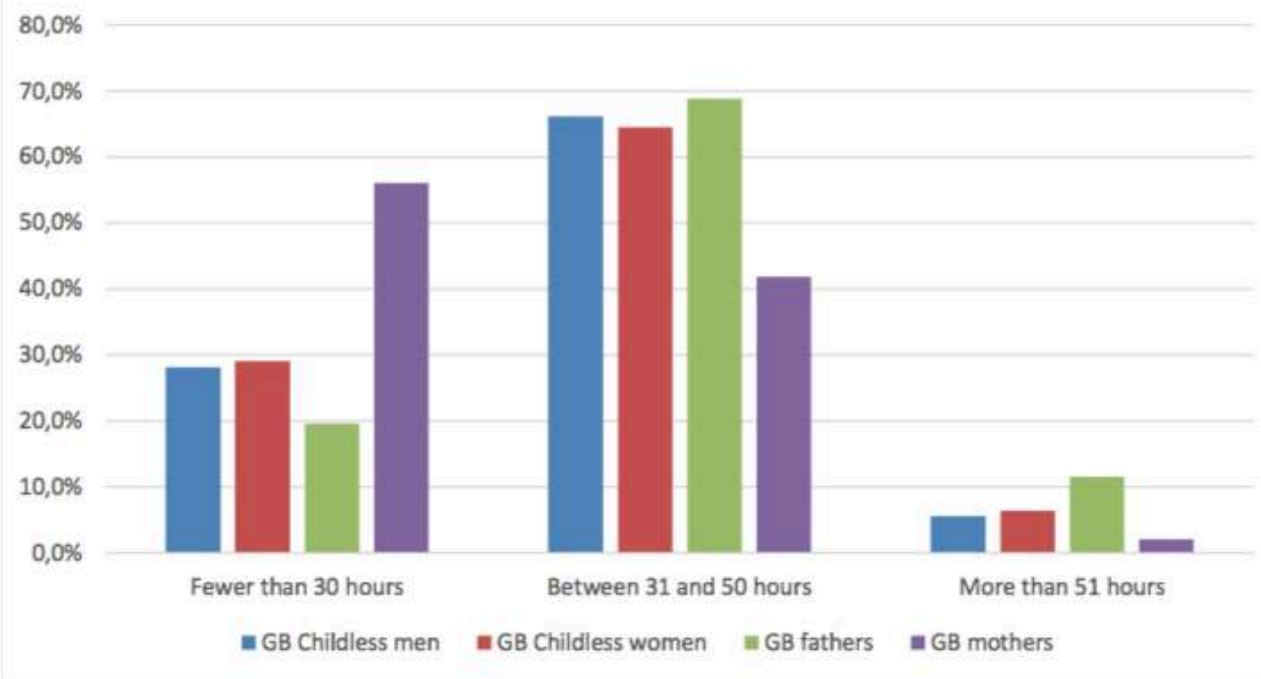

SOURCE: LOUISE DALINGWATER, CATHERINE CORON AND JEAN CORON, 2014

THIS WAS SIgNIfICANTLY HIgHER THAN IN THE FRENCH SURVEY, WHERE THE PART-TIME PERCENTAgE FOR MOTHERS WAS REPORTED TO BE MUCH LOWER (19.7\%).

Comparison of hours worked in France: Parents

vs. Childless

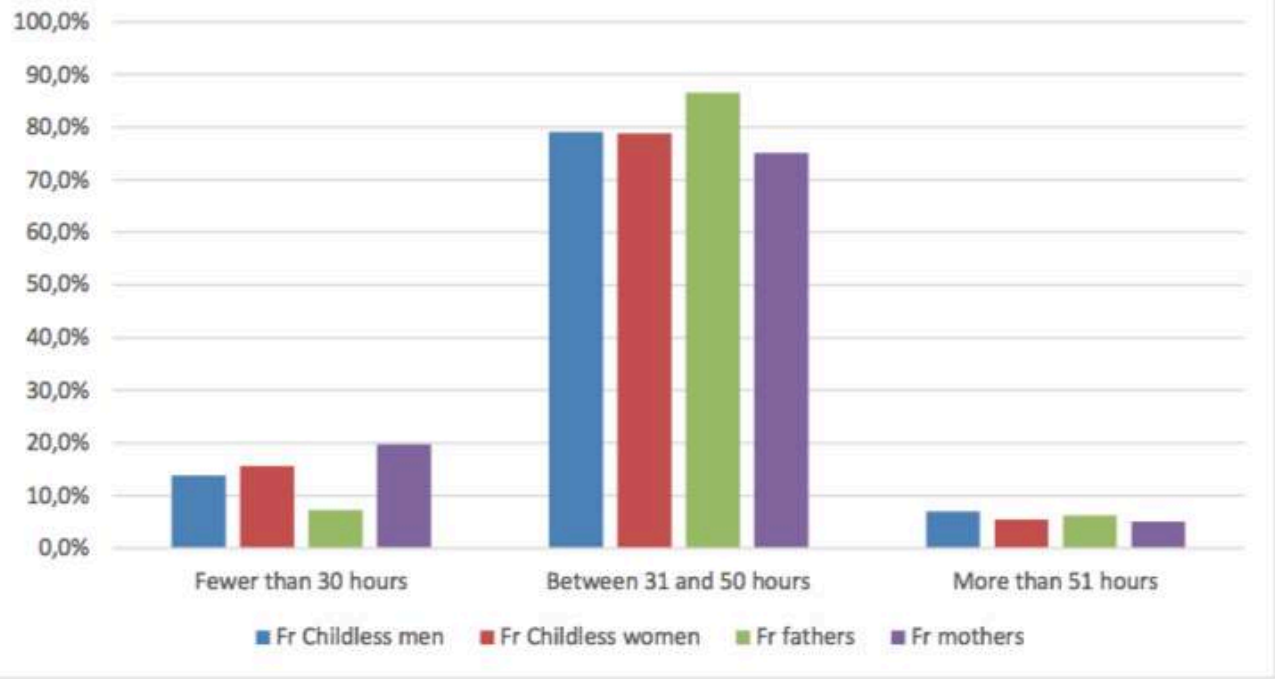

SOURCE: LOUISE DALINGWATER, CATHERINE CORON AND JEAN CORON, 2014

In Britain, the need to find family-friendly work tends to lead mothers to take on parttime, and generally less well paid, work. Despite laws to increase part-time workers' rights, there are many drawbacks to working part-time including lower hourly earnings, fewer training and promotion opportunities, fewer job opportunities, less job security, less access to unemployment insurance and reduced pension entitlements. 
This high incidence of part-time work among women has been found to incur a significant pay and opportunities gap in Britain. In the UK, this is $17.4 \%$. This is significantly higher than the OECD average of $15.6 \%$, and very close to other countries that have fully embraced the neo-liberal economic framework: the United States (17.5\%), Australia (18.0\%) and Canada (19.2\%). ${ }^{12}$ An ILO report also points to the concept of the motherhood wage gap, which suggests that inequalities in wages exist between mothers and non-mothers. According to a Glassdoor Economic Research report, the gender pay gap for women in the UK with no children is just over $7 \%$. However, for those with at least one child, the rate rises to $21 \% .^{13}$

10 The OECD underlines that the high pay gap in Britain relative to other OECD countries is due to the prevalence of part-time work in this country. ${ }^{14}$ Olsen, Gash, Vandecasteele, Walthery and Heuvelman ${ }^{15}$ were commissioned to carry out research for the Government Equalities Office to weigh up all the factors influencing the pay and opportunities gap. They found that years of part-time work was the factor that had the most influence on diminishing women's pay. Harkness' paper $^{16}$ also shows how parttime female workers have not gained from the introduction of Equal Pay and Sex Discrimination Acts in the 1970s in the same way as full time workers. Although earnings of female part-timers improved relative to male counterparts immediately after the introduction of these acts in the 1970s, the pay gap started to widen again for part-timers in the 1980s and 1990s. In 1993, for example, hourly pay of part-time women was only $63 \%$ of male mean earnings. Moreover, the main problem with parttime work is that it is overwhelmingly concentrated in low paid sectors fuelling labour market segmentation. The highest paying and highest ranking managerial, professional and associate professional occupations are predominately occupied by full-time workers. The low rated and low paid occupations in service, such as sales and other elementary positions, are occupied by more women than men and by more part-timers. After analysing the incidence of part-time across countries, the OECD has concluded that women are more likely to work part-time in countries with high childcare costs. ${ }^{17}$

11 The lack of affordable childcare and the country's tax and benefits system can reduce participation of mothers in the labour market. Stier and Lewin-Epstein ${ }^{18}$ underline that greater institutional support for maternal employment enables mothers to limit breaks from the labour market or having to take part-time low prospect jobs. Esping-Anderson noted that only welfare policies that support daycare lead to high employment for women with young children. In Britain, parenthood is seen as an individual and private choice. The state is therefore not considered to be responsible for providing the necessary facilities at an affordable price to enable women to have easier access to paid work. If women are unable to purchase care on the market, they may withdraw from the labour market altogether.

The influence of neo-liberalism is thus apparent in this issue of childcare, which stresses the individual above state intervention. With the rise of neo-liberalism in Britain, the role of the market and voluntary sector in the provision of childcare has become central. This has thus reinforced the male-breadwinner society. By making childcare a private responsibility and that of women, it has led to part-time, discontinuous patterns of work for mothers and a rise in low wages, especially for the less well-educated, who do not enjoy the same conditions of maternity leave and/or cannot afford childcare. 
Research carried out by Gash ${ }^{19}$ showed that workers in France and Denmark were able to move between full and part-time work quite easily because of adequate provision of childcare. This was very difficult in Britain, where workers are constrained by less favourable childcare conditions and less job mobility, which seems to suggest that parttime work may be more of a constraint than a choice. While local authority childcare places have decreased, Britain has witnessed a spectacular increase in the number of private nurseries and child minders. Despite the introduction of a Child Care Allowance for low income working parents and a nursery voucher scheme in 1994 under John Major and the introduction of the expansion of early childhood and childcare services under the National Childcare Strategy (leading to new paternity and parental leave and flexible working arrangements), Britain still lacks childcare state support. Childcare in Britain typically costs a quarter of female earnings and few employers provide nurseries on site. Inequalities in Britain persist therefore between mothers in low-paid jobs and those with a better education on higher incomes who can afford to pay for private care. Social class is influential in Britain because of the highly deregulated labour market which means that there is a wider spread of earnings and a residual welfare state.

In addition, austerity measures taken, in line with neo-liberal rationalisation since 2010 have only served to exacerbate the childcare dilemma. The coalition government in office between 2010 and 2015 cut child tax credits but also reduced local government budgets and these have hit women hard. Childcare provision in low income neighbourhoods has declined as a result of fiscal consolidation. The introduction of universal credit to rationalise benefits has also reduced work incentives for the second income earner - mostly women. The House of Commons library and the UK Women's Budget Group report that 78.9 per cent of the cuts in welfare impacted on women, especially lone parents. The Runnymede Trust reviewed the 2015 Budget "welfare" reforms which comprised cuts to tax credits and a benefits cap on households with three or more children and also concluded that they disproportionately affected women. ${ }^{20}$

15 It might be expected that this pay and prospect gap which can be attributed, at least in part, to the neo-liberal policy stance in Britain might meet with revolt or opposition by workers in the market. However, the British survey found that this was not the case.

\section{Why do women consent?}

16 An area where there were quite striking differences between the surveys conducted in Britain and France was that of attitudes to equality issues, particularly regarding equal opportunities for men and women at work. Considering the aforementioned higher pay and prospect issues, it might be expected that significant issues regarding men and women at work might be raised. However, the British survey did not bring out any significant issues regarding men and women at work. However, the French reported significant gender inequality issues. For example, $79 \%$ of British workers reported that there were equal opportunities for career development for men and women at their workplace, compared to only $52 \%$ in France. The differences are even more striking when workers were asked whether their workplace discriminates between men and women in terms of earnings, with $63 \%$ of French workers reporting discrimination compared to only $9 \%$ in the UK. However, as we have mentioned previously, statistics 
do not seem to suggest that inequality is stronger on the French labour market than the British one. The opposite is true.

It might be the case that women are less aware of inequalities that exist in the labour market in Britain than in France because, as described earlier, working hours are very varied in Britain's flexible labour market, which makes pay and prospect comparisons difficult. But can we also conclude that, in the neo-liberal British labour market, profit comes before equality? The prevailing neo-liberal ideology gives primacy to the individual above state intervention and this seems to have pervaded British culture. British people seem to accept more readily the trade-off between fewer hours and lower pay and family time: individual effort and reduced working hours automatically equates with low pay and prospect in this model, and it is considered to be acceptable. This indeed might explain why there is very little discrimination reported in the British survey. An LSE report supports our theory by suggesting that this accepted payoff is due to an adherence to orthodox economics, which argues that pay reflects employees' contributions to output. ${ }^{21}$ Wages are thus considered to be fair and reflect legitimate market processes. However, other countries where neo-liberalism is less pronounced do not buy into this theory, as the French survey suggests. Critics also argue that the increase in wages in the top decile, and particularly the top 1 per cent, which is particularly significant in neo-liberal economies, such as the UK and the US, is not in line with performance or qualifications. It is more in terms of the power that managers have to negotiate their own remuneration.

In addition, beyond the neo-liberal influence, the gender conservative nature of British society should not be ignored. Crompton ${ }^{22}$ underlines that cultural norms may actually outweigh institutions. British conservative tradition means that it is still overwhelmingly women that undertake domestic chores: on average 2 hours 40 minutes a day for women and 1 hour 25 minutes per day for men. ${ }^{23}$ Moreover, in 2012, nine in ten people polled in Britain still stated that the mother should be the sole or main carer of children and that the ideal division is the mother working part time and the father full time. ${ }^{24}$ So we can see not only the influence of the economic model but also the social model. Women may adjust employment and childcare behavior to fit the cultural family model prevalent in their country or community.

\section{Further statistical evidence: increased participation but horizontal segregation}

19 Furthermore, it has been argued that neoliberalism has increased participation, but reinforced horizontal segregation. This goes beyond the scope of the two-nation survey, so only secondary sources have been used to analyse this theory.

Many OECD countries have experienced a significant increase in the participation of women in the labour market and Britain is no exception. In Britain, the participation rate has increased significantly since the 1960 s to reach $72.1 \%$ for $15-64$ year olds. This is still lower than for men (83.1\%), but part of the gap can be explained by the fact that women tend to study for longer. If only 25 to 54 year olds are taken into consideration, 75.3\% of British women are currently in paid work.

21 Although participation rates and participation gaps are not so different from many other European countries that have not seen neo-liberalism as the overriding model 
adopted by central government, neo-liberal countries do comparatively better compared to other countries. The OECD average is $62.8 \%$ which is substantially lower than Australia (70.5\%), Canada (74.2\%) and Britain (72.1\%). The flexible nature of the neo-liberal labour market in Britain and much of the Anglosphere could explain why Britain and other neo-liberal labour markets perform relatively well compared to other countries with more stringent labour market legislation. The neo-liberal policy changes that were introduced in the 1980s, to free up the market through deregulation of the labour market, financial liberalisation and privatisation of public services have thus led to a massive increase in the number of jobs available and a fall in unemployment.

Indeed, in Britain, neo-liberal reforms would seem to have increased female participation. The rise in single person households led to the creation of government policies in the late 1990s to get lone mothers into work, supported by a shift in perspective from welfare to workfare. In order to receive benefits, people are now forced to take responsibility and take on work. Workfare started in the 1980s under the Conservative governments, but was particularly the focus of New Labour governments (1997-2010). It has paved the way for further stringent welfare reforms under successive governments to force people to work.

Nevertheless, neo-liberalism is not the only reason for the increased participation in the labour market. In Britain, the Equal Pay Act of 1970, the Sex Discrimination Act of 1974 and the Employment Protection Act of 1982 were instrumental in reducing discrimination in terms of pay and opportunities for women in the workplace and thus boosting participation rates. Increasing numbers of women have entered higher education and want to use the skills gained.

The rise in the participation rate of women in Great Britain since the 1970s is also directly related to the move towards a service economy, which provides more varied and flexible working arrangements, and thus enables women to fit work around caring for young children. Many service jobs require general rather than specific skills which means that women and, in particular, mothers do not have to commit to long and uninterrupted careers. In general, this is not the case for manufacturing jobs where each industry and each firm tends to have its own production and management techniques, which makes it difficult for such interruptions to take place. The demand for female labour, which requires more general skills and less commitment, has risen with the service sector. Iversen and Rosenbluth also point to higher divorce rates which have encouraged women to become more independent and earn their own income in order to avoid poverty. ${ }^{25}$ Indeed, $14.6 \%$ of marriages ended in divorce in 1970, whereas the figure was as high as 50\% in 2005 in the UK. However, the type of job offered to women tends to be of the low paid, low prospect type. There has thus been a rise in the participation of women in the labour market, but there has also been an increase in low skilled and low paid work for women. The service sector jobs which require general rather than specific skills are mainly low paid and low prospect jobs. A UK labour force survey carried out in April 2015 showed that a higher proportion of women than men worked in sectors such as administration and caring, which tend to be low paid.

25 A term has even been coined to refer to such a trend: horizontal segregation. Women tend to cluster in low paid jobs and, even at the same occupational level, men and women tend to be assigned different job tasks. Therefore, service sector jobs have increased participation, but have also led to increased segregation and this can also 
explain the pay and prospects gap in Britain, but this is very true of many other countries too. Evidence from France, Canada, the UK and the US shows the increasing feminisation of certain sectors or so-called "pink collar professions": namely entire subsectors of health and education, which can produce reduced wage growth. In Britain, the Kingmill Report on Women's Employment and Pay also showed that occupational segregation is significant in the British labour market. Out of 77 recognised occupational groups, $60 \%$ of females were present in only ten of these groups. A study carried out by the European Union underlines the gender bias in the British economy. The commission measured the top 5 preferred sectors of work for women and men and found only two common sectors ("Wholesale \& Retail", "Professional, scientific and technical activities"). $19.8 \%$ of female workers and $20.4 \%$ of the male workforce work in these sectors. However, the most preferred sector for women is undoubtedly Health and Social Work, representing $40 \%$ of total female employment but less than $7 \%$ of male jobs. Overall, it was found that women prefer service and education occupations and men technical and engineering occupations. In addition, according to an LSE report, women still cluster in the 3Cs (Caring, Clerking and Cashiering) and men in the Skilled Trade Occupations which pay more.

Segregation starts at school. Indeed, girls outperform boys in reading but lag behind in maths, because of gender-imposed ideas about what is male work and female work. Research has shown that even women who study STEM subjects (science, technology, engineering and maths) are less likely to end up working in employment that uses physics, engineering or maths. Even though differences in occupational choices can be traced back to differences in educational choices, occupational segregation is further reinforced in the transition from post-secondary education to employment. $71 \%$ of male graduates from the science fields work as professionals in physics, maths, and engineering compared to $43 \%$ of female graduates. In other words, even if women choose STEM subjects they are less likely to pursue a science career than men, although there is no gender difference in performance.

Despite the fact that horizontal segregation is prevalent in countries that have not experienced a restructuring of the labour market due to neo-liberal policies, evidence suggests that horizontal segregation is higher in Britain than the EU average. Indeed, the European Commission has devised an occupational gender segregation (OGS) indicator. According to this indicator, gender segregation is calculated to be $5.5 \mathrm{pp}$ in Britain, which is higher than the overall OGS of the EU-27 (4.6 pp). ${ }^{26}$ While neoliberalism cannot explain away all gender inequalities, neo-liberal policies do seem to have exacerbated these differences between the British labour market and other developed economies.

\section{Conclusion}

Some authors have argued that market liberalisation has contributed to women's empowerment because of the higher participation rates. However, the evidence presented in this article would seem to suggest that while neo-liberal policies in Britain have given rise to what critics call a "feminization" of labour, they have also been accompanied by a deterioration of working conditions - casualisation, flexibilisation and low wages. ${ }^{27}$ The move towards a service economy has also led to increased participation and more flexible forms of work in most developed countries. 
Nevertheless, a slightly higher participation rate for women in Britain may be linked to a more flexible labour market, which has led to the creation of a vast number of jobs providing atypical working hours for women. The pay and prospects gap overall was found to be relatively high in Britain compared to many other OECD countries. Both the theoretical and evidence-based approach suggests that these differences can be linked in part to the neo-liberal framework in Britain. A certain degree of gender conservatism towards motherhood in Britain might also explain why women tend to work part-time and thus incur a higher pay and prospect penalty.

The comparative study goes even further and explores the acceptance of neoliberal ideas by the workers themselves and suggests that there has been an internalisation of neoliberal principles in Britain's labour market. This would seem to suggest that the efficiency of neo-liberalism in Britain rests on how deep-seated an individual's understanding of the world is. Thus, even those who are clearly losing out in the neoliberal economy see inequalities as "natural" or "justified", which might be linked to Antonio Gramsci's idea of cultural hegemony. ${ }^{28}$ However, to confirm such a thesis, it would be necessary to widen such a survey to other countries and to test for a greater number of factors.

Despite this rationalisation of the British labour market as a result of neo-liberalism, some progress has been made in terms of gender equality. In 2011, Public Sector Equality Duties were introduced to protect the elderly, the disabled, pregnant women and women on maternity leave, and to ensure equality. In terms of government representation, ministers have set a target to increase female representation by $25 \%$. Board positions in the FTSE for women have also been increased to $20.7 \%$ compared with 12.5\% in 2011 and 17.3\% in April 2013. ${ }^{29}$ David Cameron called for an end to "the gender pay gap in a generation" during a Conservative Party Conference in 2015.30 Theresea May has also recently sought to have an equal number of women in the cabinet. However, such measures will not solve the problem of horizontal segregation because women will continue to be over-represented in low-wage sectors. It might also be added that if workers continue to internalise neoliberal principles, and thus underestimate or fail to give importance to underlying gender inequalities in the labour market, it could thwart any attempts to reduce labour market disparities between men and women.

Louise Dalingwater is an Associate Professor of British Studies at Paris Sorbonne Nouvelle University. Her research focuses on the service sector, with a particular interest in changes that have occurred in the labour market since the 1970s and the move towards a service-oriented economy. She is currently leading a research project at her research centre (CERVEPAS) on wellbeing in English-Speaking countries. 


\section{BIBLIOGRAPHY}

Alesina, A., Di Tella, R. \& MacCulloch, R., 'Inequality and happiness: Are Europeans and Americans different?', Journal of Public Economics, 88, 2004, pp. 2009-2042.

Alsop, R., Bertelsen, M. \& Holland, J., Empowerment in Practice: From Analysis to Implementation (Washington, World Bank, 2006).

Clarke, A. \& Senik, C., Who Compares to Whom? The Anatomy of Income Comparisons in Europe (Bonn , IZA Discussion Paper 4414, 2009).

Crompton, R., Employment and the Family. The Reconfiguration of Work and Family Life in Contemporary Societies (Cambridge and New York, Cambridge University Press, 2004).

Eisenstein, H., Feminism Seduced: How Global Elites use Women's Labour to Exploit the World (CO, Boulder, Paradigm, 2009).

Elson, D., 'Male Bias in Structural Adjustment', in H. Afshar and C. Dennis (eds), Women and Adjustment Policies in the Third World (New York, St Martin's, 1992).

Equalities and Human Rights Commission, How Fair is Britain?, <www.equalityhumanrights.com>, 2012 accessed on 12 July 2014.

European Commission, Gender Impact Assessment: United Kingdom (Brussels, EC, 2014).

Fraser, N., 'Feminism, capitalism and the cunning of history', New Left Review 56, 2009, pp. 97-117.

Gash, V., 'Preference or Constraint? Part-time Workers' Transitions in Denmark, France and the United-Kingdom', Work, Employment and Society, 22 (4), 22 (4), 2008, pp. 655-674.

Glassdoor Economic Research, Which Countries in Europe Have the Best Gender Equality in the Workplace?, (London, Llewellyn Consulting, Glassdoor Economic Research, 2016).

Grosfeld, I. \& Senik, C., 'La montée de l'aversion à l'inégalité. Du temps des anticipations au temps de la déception', Revue économique 60, 3 mai 2009.

Hakness, S., 'The Gender Earnings Gap: Evidence from the UK', Fiscal Studies, 17, 2, 1996, pp. 1-36.

Hawkesworth, M., 'Feminists v. Feminization: Confronting the War Logics of the Bush Administration', Asteriskos 1/2, 2006, pp. 117-42.

Iversen, T. \& Rothenbluth, F., Women, Work and Politics (New Haven, Yale University Press, 2010). International Labour Office, Decent Work Indicators: Concepts and Definitions (Geneva, ILO, 2012). Lelkes, O., 'Attitudes to Inequality', in TARKI European Social Report 2009 (Budapest, 2009), pp. 1730.

LSE, Confronting Gender Equality (London, LSE, 2015).

McRobbie, A., The Aftermath of Feminism: Gender, Culture and Social Change (London, Sage, 2009).

Moghadam, V., Globalizing Women: Transnational Feminist Networks (Baltimore, Johns Hopkins University Press, 2005).

OECD, OECD Data, 2015, <https://data.oecd.org/emp/labour-force-participation-rate.htm> accessed on 15 June 2016.

OECD, Closing the Gender Gap (Paris, OECD, 2012). 
Park, A., Clery, C., Curtice, J., Phillips, M. \& Utting, D., British Social Attitudes (London, Natcen Social Research, 2012).

Sen, A., Inequality Re-examined (New York, Russell Sage Foundation, 1992).

Simon, R., Gramsci's Political Thought: An Introduction (Lawrence and Wishart, London, 1991).

Sparr, P. (ed.), Mortgaging Women's Lives: Feminist Critiques of Structural Adjustment (London, Zed Books, 1995).

Stier, H., N. Lewin-Epstein, and M. Braun. 'Welfare Regimes, Family Supportive Policies, and Women's Employment Along A Life Course', American Journal of Sociology 106(6), 2001.

UK Government press release, Prime Minister: My one nation government will close the gender pay gap, 2015, Available at: <https://www.gov.uk/government/news/prime-minister-my-one-nationgovernment-will-close-the-gender-pay-gap> consulted on 18 June 2016.

UK Government, Women on boards: Davies Review Annual Report 2014, available at: <https:// www.gov.uk/government/uploads/system/uploads/attachment_data/file/297519/bis-womenon-boards-2014.pdf> consulted on 18 June 2016.

\section{NOTES}

1. International Labour Office, Decent Work Indicators: Concepts and Definitions (Geneva, ILO, 2012).

2. Encyclopaedia Britannica, https://global.britannica.com/topic/neoliberalism consulted 15 march 2017.

3. D. Elson, "Male Bias in Structural Adjustment", in Afshar, H. and Dennis, C. (eds), Women and Adjustment Policies in the Third World (New York, St Martin's, 1992).

4. M. Hawkesworth, "Feminists v. Feminization: Confronting the War Logics of the Bush Administration", Asteriskos 1/2, 2006, pp. 117-42.

5. H. Eisenstein, Feminism Seduced: How Global Elites Use Women's Labour to Exploit the World (CO, Boulder, Paradigm, 2009).

6. N. Fraser, "Feminism, Capitalism and the Cunning of History", New Left Review 56, 2009, pp. 97117.

7. A. McRobbie, The Aftermath of Feminism: Gender, Culture and Social Change (London, Sage, 2009).

8. Alsop, R., Bertelsen, M., \& Holland, J. Empowerment in Practice: From Analysis to Implementation (Washington, World Bank, 2006).

9. A. Sen, Inequality Re-examined (New York, Russell Sage Foundation, 1992); Alesina, A., Di Tella, R. \& Maccullogh, R., "Inequality and happiness: Are Europeans and Americans different?" Journal of Public Economics, 88, 2004, pp. 2009-2042; Clarke, A. \& Senik, C., Who Compares to Whom? The Anatomy of Income Comparisons in Europe (Bonn, IZA Discussion Paper 4414, 2009); Grosfeld, I. \& Senik, C., "La montée de l'aversion à l'inégalité. Du temps des anticipations au temps de la déception", Revue économique 60, 3, mai 2009; Lelkes, O., “Attitudes to Inequality" in TARKI European Social Report (Budapest, 2009), pp. 17-30.

10. In the UK, there is no specification for the number of hours that constitute part-time work. However, a part-time worker is defined as someone who works fewer hours than a full-time worker. A standard working week for a full time worker in the UK is 35 hours or more.

11. OECD, OECD Data , <https://data.oecd.org/emp/labour-force-participation-rate.htm> accessed on 15 June 2016.

12. OECD, Closing the Gender Gap (Paris, OECD, 2012). 
13. Glassdoor Economic Research, Which Countries in Europe Have the Best Gender Equality in the Workplace? (London, Llewellyn Consulting, Glassdoor Economic Research, 2015).

14. OECD, Closing the Gender Gap, op.cit.

15. Equalities and Human Rights Commission (EHRC), How Fair is Britain?, $<$ www.equalityhumanrights.com>, 2012 (accessed on 12 July 2014).

16. S. Harkness, "The Gender Earnings Gap: Evidence from the UK”, Fiscal Studies, 17, 2, 1996, pp. $1-36$.

17. OECD, Closing the Gender Gap, op.cit.

18. Stier, H., Lewin-Epstein, N. \& Braun, M., "Welfare Regimes, Family Supportive Policies, and Women's Employment Along A Life Course", American Journal of Sociology, 106(6), 2001.

19. V. Gash, "Preference or Constraint? Part-time Workers' Transitions in Denmark, France and the United-Kingdom", Work, Employment and Society, 22 (4), 2008, pp. 655-674.

20. LSE, Confronting Gender Equality (London, LSE, 2015).

21. LSE, Confronting Gender Equality, op.cit.

22. R. Crompton, Employment and the Family. The Reconfiguration of Work and Family Life in Contemporary Societies (Cambridge and New York, Cambridge University Press, 2004).

23. OECD, Closing the Gender Gap, op.cit.

24. Park, A., Clery, E., Curtice, J., Phillips, M. \& Utting, D., British Social Attitudes (London, Natcen Social Research, 2012).

25. Iversen, T. \& Rothenbluth, F., Women, Work and Politics (New Haven, Yale University Press, 2010).

26. European Commission, Gender Impact Assessment: United Kingdom, Brussels, EC, 2014.

27. V. Moghadam, Globalizing Women: Transnational Feminist Networks (Baltimore, Johns Hopkins University Press, 2005).

28. R. Simon, Gramsci's Political Thought: An introduction, (Lawrence and Wishart, London, Routledge, 1991). Based on Karl Marx's theory, Antonio Gramsci argued that the dominant ideology of society reflected the beliefs and interests of the ruling class. In the case of Britain, we are referring to the top $1 \%$. This dominant ideology is then spread to social institutions such as education, media, family, religion, politics, and law, among others. Cultural hegemony is thought to be strongest when the group that is dominated by the ideology start to believe that the economic and social conditions are "natural" or "justified", rather than created by people with a vested interest in particular social, economic, and political orders.

29. UK Government, Women on boards: Davies Review Annual Report 2014, available at: <https:// www.gov.uk/government/uploads/system/uploads/attachment_data/file/297519/bis-womenon-boards-2014.pdf> consulted on 18 June 2016.

30. UK Government press release, Prime Minister: My one nation government will close the gender pay gap, 2015, available at: <https://www.gov.uk/government/news/prime-minister-my-one-nationgovernment-will-close-the-gender-pay-gap> consulted on 18 June 2016.

\section{ABSTRACTS}

There has been a significant rise in the number of women working in Britain since the 1970s. This rise is directly related to the move towards a service economy and also higher levels of education and training. In addition, a series of laws introduced since the 1970s, notably the Equal Pay Act of 
1970, the Sex Discrimination Act of 1974 and the Employment Protection Act of 1982, have encouraged women to work. However, there appears to be a discrepancy between the quantity of work available for women and the quality. Quality work, as defined by the International Labour Organisation (ILO), can be described as work that provides decent pay, and offers development and progression opportunities. Many of the jobs created in the service sector and largely occupied by women tend to be low paid and low prospect "pink-collar" jobs, failing to meet many of the "decent work" recommendations of the ILO. Women tend to cluster in flexible service sector jobs such as infant school assistants, home helps and domestic helpers.

Although this is true of many industrialised countries with very different labour market conditions such as France and Germany, the pay and prospects gap for women is considerably higher in Britain. There are, of course, a number of causal effects. However, a body of evidence suggests that higher gender inequalities at work may be linked to neo-liberalism in Britain. The influence of neo-liberalism has not only shaped legislation in Britain but also attitudes to women and work since the 1970s. Indeed, after analysing the results of a nationwide survey carried out across Britain and France in 2014 on wellbeing at work, this article shows how British attitudes to inequalities at work are shaped by the neo-liberal model and may have serious implications for future policies to improve pay and prospects for women working in Britain. It will thus explore the influence of neo-liberalism in Britain on career pay and prospects in Britain, taking both a theoretical and evidence-based approach.

Nous constatons une augmentation significative du nombre de femmes sur le marché du travail au Royaume-Uni depuis les années 1970. Cette hausse est directement liée à l'évolution vers une économie de services et à l'élévation du niveau de formation des femmes. En outre, l'introduction d'une série de lois depuis les années 1970, notamment la loi sur l'égalité salariale de 1970, la loi sur la discrimination sexuelle de 1974 et la loi sur la protection de l'emploi de 1982, a encouragé les femmes à travailler. Cependant, il semble y avoir une différence entre la quantité de travail disponible pour les femmes et la qualité. Un travail de qualité, tel que défini par l'Organisation internationale du Travail (OIT), est un travail qui offre un salaire décent et des possibilités de développement et d'évolution. Cependant, la plupart des emplois créés dans le secteur des services et en grande partie occupés par des femmes ont tendance à être faiblement rémunérés et peu qualifiés, des emplois "cols roses», qui ne correspondent pas aux critères du «travail décent» de l'OIT. Les femmes ont tendance à se regrouper dans des emplois flexibles du secteur des services tels que les nourrices, les aides à domicile et les travailleurs domestiques.

Bien que cela existe dans de nombreux pays industrialisés avec des conditions très différentes du marché du travail, comme la France et l'Allemagne, l'écart de rémunération et de perspectives entre les hommes et les femmes est beaucoup plus important en Grande-Bretagne. Il y a, bien sûr, un certain nombre d'effets de causalité. Cependant, certains auteurs ont noté une corrélation entre la hausse des inégalités au travail et le modèle néolibéral qui domine en Grande-Bretagne. L'influence du néolibéralisme n'a pas seulement influencé les politiques et la législation du marché du travail en Grande-Bretagne, mais aussi les attitudes envers les femmes et le travail depuis les années 1970. En effet, après avoir analysé les résultats d'une enquête nationale menée au Royaume-Uni et en France en 2014 sur le bien-être au travail, cet article montre comment la perception des inégalités au travail sont façonnées par le modèle néolibéral et peut avoir de graves conséquences pour les politiques futures sur le marché du travail au Royaume-Uni. Il propose donc d'explorer l'influence du néolibéralisme au Royaume-Uni sur les salaires et les perspectives d'évolution pour les femmes en Grande-Bretagne, en prenant à la fois une approche théorique et empirique. 
INDEX

Mots-clés: Neo-liberalism and Gender Inequality in the Workplace in Britain

Keywords: Neo-liberalism, Gender Inequality, British Labour Market, Horizontal segregation, Nationwide survey

\section{AUTHOR}

LOUISE DALINGWATER

CREW, Université Sorbonne Nouvelle - Paris 3 